\title{
Legal Philosophy of Pancasila as The Paradigm of The Criminal Justice System: A Philosophical Criticism for the Loss of a Sense of Humanity
}

\author{
Rocky Marbun ${ }^{1 *}$, Abdul Hakim ${ }^{1}$ and M. Adystia Sunggara ${ }^{2}$ \\ ${ }^{1}$ Faculty of Law, Pancasila University, Jakarta, Indonesia \\ ${ }^{2}$ Law Firm Adystia Sunggara \& Associates, Pangkalpinang, Bangka, Indonesia
}

\begin{abstract}
Since 1981, marked by the enactment of law number 8 of 1981 on criminal procedure law, it has become a consensus to abandon the Cartesian paradigm embodied in the inquisitoire principle. The inquisitoire principle sees any person drawn into a criminal justice struggle as an object. The Criminal Procedure Code (CPC) through the philosophical foundation of Pancasila, commands to adopt the accusatoire principle, in honor of the withdrawn party as a person entirely. However, the KUHAP/CPC formers forget the institutional legal culture of the thrown (gowerfen-sein) criminal justice system in the myth of modernity that is the objectification of human being. So that the law enforcement officers (investigators, public prosecutors, judges) always ignore Pancasila as the philosophical foundation of thought in carrying out the law.
\end{abstract}

\section{Introduction and literature review}

Indonesian people gained their freedom from colonialism through struggles for independence. It led to a very fundamental consequence in the development of the history of the nation, country, and life of the community. It is widely acknowledged that the principle of concordance which provides legal political foundation to apply foreign legal systems into the living spheres of law in Indonesia is only temporary, as written in the Article II Transitional Rules of the 1945 Constitution (Pre-Amendment) which claiming "All existing bodies and regulations still prevail as long as new stipulations have not been enacted according to this Constitution." The stipulation has been maintained after four amendments, yet it is broken down into two articles; Article I Transitional Rules and Article II Transitional Rules.

Although the principle of concordance is the basis of the national political law, the spirit of the exemption does actually emerge in the Paragraph IV of the 1945 Constitution of the Republic of Indonesia as the philosophical foundation that asserts "....shall be formulated into a constitution of the Republic of Indonesia which shall be built into a sovereign state based on: a belief in the One and Only God, a just and civilized humanity, a unified

\footnotetext{
${ }^{*}$ Corresponding author: rocky.marbun08@gmail.com
} 
Indonesia, the democracy which is led by wisdom of thoughts in deliberation amongst representatives of the people, and achieving social justice for all the people of Indonesia."

However, it seems that the colonialism heirdom brings ways and thinking patterns in every institution of law enforcers, presuming that it is the right thing. Authors do not say that uniformity is a must in the method employed, but rather emphasize more on what underlies the use of the method, or in the other words, the paradigm utilized in designing a method for reviewing legal issues, particularly the criminal law.

Widodo Dwi Putra [1] argues that the paradigm of law in Indonesia hardly has any theoretical debates among law-bearers, let alone the emergence of a new "school". The paradigm of law has been stagnated in which the Legal Positivism Paradigm never experienced what Thomas Kuhn called as an "anomaly", signifying that Legal Positivism Paradigm remains to exist in common sciences from generation to generation in the law practice.

If the formal law is useful to enforce criminal law, then the issues of how to enforce will not be questioned. Therefore, the interpretation towards the principle of legality has shifted from the efforts to protect human rights, becoming ways of punishing the Suspect/Defendant. Thus, the conclusion method employs syllogism meaning to merely satisfy the elements of the authoritative text as the major premise. This study only focuses on the problems regarding to the philosophical foundation that should be used in the criminal justice practice in order to emerge the respect towards human dignity and prestige in the Criminal Justice System in Indonesia.

\subsection{Understanding and Finding Legal Philosophy in the Criminal Justice System in Indonesia}

\subsubsection{The Philosophical Foundation in the Criminal Law System}

According to Jimly Assihiddiqie[2], a way of life in the context of Indonesia's thing is Pancasila that it is a mutual agreement or general consensus of the majority people in the country. If the general agreement is falling apart, it will also happen to the legitimacy of the country authority, causing a civil war or a revolution. As a consequence, the interpretation towards Pancasila as a philosophy should not be understood as the five principles of the nation, but it is only one principle. Pancasila as the underlying philosophy of the country is unity with its single compound composition.[3] Those five elements are the part of an entire entity and in an inseparable way so that each element must be absolute as a representation of the entire entity.

The researchers' argument comes from a perspective that the formation of Pancasila is based on several reasons. It is based on assumptions that everything created by humans must have a purpose. Pancasila that "is created" --- in the sense of pulling out --- by the Indonesian Nation does also have a purpose as the principle of the nation. Hence, Darji Darmodiharjo and Shidarta[4] claim that Pancasila has a main function as the national principle of the Republic of Indonesia from the perspective of its functions. From the perspective of its material, Pancasila is excavated from the view of life of the nation which is the soul and personality of the Indonesian nation itself. Pancasila is created by "domestic" material as the pure material and has become the nation's pride.

\subsubsection{Indonesian Man As Material Object Of Pancasila Philosophy}

Notonagoro[5] states that Indonesian people is the monopluralis creature, i.e. (1) position of nature, Indonesian people are individuals who stand alone and are God's creations; (2). 
structure of nature, Indonesian people consist of body and soul elements; (3) character of nature, Indonesian people have individual and social elements. Those three elements should be balanced and dynamic so that it creates a balance between physical and spiritual interests, individual and social life interests, independent personal and religious interests that are directed consistently, dynamically, and in balance. [6] Roeslan Abdoelgani[7] notes that the balance of spiritual and physical values can be achieved in Pancasila.

The quest for those basic values is in order to find out the axiological meaning (the nature of value) of Pancasila. Thus, Notonagoro[8] argues that the values of Pancasila are categorized as the spiritual values, acknowledging the existence of material and vital values. The values of Pancasila which are categorized as the systematic-hierarchical values of spiritual, beauty, and moral. It is started from the first principle of Pancasila "A Belief in the One and Only God" as the "principle" to the last principle "Social Justice for all the people of Indonesia" as the "purpose".

Such ways of thinking is certainly become unfamiliar for today's scientists. Regarding to this, Bernard Arief Sidharta[9] confirms that the starting point of Indonesia's way of life is a belief that men are created in communion with his fellows; individuals and their association of life (society) are a duality. Therefore, communion with his fellows or life association is the essential element in human existence. The elements of the body, feeling, and ratio are creating the aspect of individualism of humans, and the element of harmony realizes the aspect of the sociality of humans; individualism and sociality aspects are inseparable from each other.

The principle of harmony as defined by Soediman Kartohadiprodjo[10] is the complementary tool for human in addition to Body, Feeling, and Ratio in group life and they are inseparable from each other. Furthermore, they want to live together for some reasons, based on the Family Principle as the soul of Pancasila. If people see their life goal is living happily as previously elaborated, then the only way to arrive at that phase of life is by utilizing their life complementary tools excellently, such as a discussion and agreement. The discussion or agreement is the way to have meaningful happiness.

\subsection{Juridical Foundation of the Existence of Philosophy of Pancasila as the Base of Law Reasoning}

In order to find out the existence of philosophical foundation in the process of Criminal Law System --particularly Criminal Justice System in Indonesia, we need to go back to the activity of Law Sciences, i.e., interpretative cognitive activities-based exposure stage and systematization stage that are subjected to the principle of cognitive arrangement of semantic units. [11] Thus, the researchers compile laws and regulation systematicallyhierarchically prevailed currently in Indonesia. As noted by Otong Rosadi[12] that for Indonesian Nation, Pancasila in the 1945 Constitution does not only outline the purpose of the country but also provide the principal rules of the country that are fundamental and become the foundation of laws and regulation formulation.

In a normative juridical way, Article 2 of Law Number 12 of 2011 claiming "Pancasila is the source of all sources of state law". Article 2 Section (2) of Law Number 48 of 2009 claiming "State justice applies and enforces law and justice based on Pancasila." Furthermore, Consideration Considers letter a of the CPC asserting "that the Republic of Indonesia is a country of law that is based on Pancasila and the 1945 Constitution and upholds human rights as well as guarantee that all citizens are in the same before the law and government, and are obliged to uphold the law and government with no exceptions."

By referring to Aulis Aarnio[13] that law science is the study of meanings, then, in order to make an interpretation in the stage of exposure and systematization, the concepts of 
law mastery are required, so that fallacy in legal reasoning and argumentation will not occur.

\section{Objective of study}

The objective of this study is to explore the process of criminal justice that is not in a legal system which is allowed to move without a standard system of legal reasoning through the philosophical foundation that is acknowledged as the legal philosophical foundation and is acknowledged by the country.

\section{Methodology}

This study employed a normative juridical method with secondary data collected by library research activities. The logical consequence of the use of such a method is the utilization of philosophical and conceptual approaches.

\section{Discussion}

An interesting part in the practice of criminal justice is that as if there was a clear separation between judicial theory and practice. Even the form of the separation spreads over the independence of each law field. As if each law field only regulated in their own field without accommodating other fields of law that are actually the founders of the related field. In this case, the researchers do not mean to be stuck merely in historical aspects, yet we consider the existence of a whole sequence of the emergence of each field. The separation process in the law field turns out bringing an impact on the interpretation of a similar concept, yet it is interpreted differently by each field of law.

This study provides an example of the meaning shift of the principle of legality, in which historically, it is a principle of protection and a reaction towards the rulers' arbitrariness in the days of the ancient regime as well as the answers of functional needs towards the legal certainty that becomes a must in a State of Liberal Law in that era.[14] This principle is very effective in protecting people from the rulers' arbitrariness. However, it is considered ineffective for law enforcers in responding to the rapid development of crime. Such an interpretation, in essence, is coherent with the emergence of the principle of law state that is based on respect for human rights over the behavior of the arbitrariness of the time.

Over time, the interpretation is shifted into a latin adagium, i.e., nullum delictum nulla poena sine praevia lege poenali. According to Groenhuijsen, the development of legality principle is shifted into the legitimacy of the country's authority to intervene through the application of law legally.[15] Such an interpretation affects on how the Academician and Practitioner of Criminal Law give a meaning to the CPC. This is certainly inseparable from the paradigm that dominates and hegemonizes the pattern of legal reasoning in Indonesia.

That pattern of legal reasoning can actually be tracked by how the country formulates an authoritative text. It is too arbitrary if the country directly assigns it based on practical experiences. Therefore, we can examine several articles which show indications of the dominance and hegemony of classical legal positivism-nuanced reasoning. This study can certainly be started from the purposes of the CPC itself, as set out in the Consideration Considering letter $\mathrm{c}$ of CPC which has the following purposes: (1) people can live their rights and responsibilities; (2) improving behavior development of law enforcers; (3) encouraging law enforcers to enforce the law based on functions and authorities towards the upholding of law, justice and protection of human dignity, order and legal certainty; and (4) 
all attitudes and actions of law enforcers aim to perform the principle of law country based on constitution.

Those purposes have a reasoning basis, according to the set paradigm in the Consideration Considering letter a CPC, i.e., based on Pancasila and Constitution as the guarantee towards the principle of equality before the law and respect for human rights. Referring to the interpretation of Pancasila as the way of life of the Indonesia, the nature of the interpretation is a form of an unarbitrary reasoning pattern. Similarly, the interpretation of human rights indubitably depends on the cultural elements within themselves. Nevertheless, the interpretation immensity has been reduced through the arrangement of the CPC itself.

Pancasila as a philosophy has Indonesian people as its material object. Therefore, all aspects that make a person as a whole person also determine every action. The entire expression of life appreciation is certainly not able to be given in a whole in every word. Even, oral communication will experience a meaning reduction due to the process of word selection to be given. This process will not be taught in college, yet it comes from the inspection process at the Pre-Adjudication stage. Hence, the principle of accusatoir proclaimed in the philosophical foundation and politics of law of the Criminal Procedure Code is lost. Therefore, the inspected remains as the object of the inspector.

The respect for the human rights aspect is increasingly lost when it is traced to the interpretation understood by the Academician and Criminal Law Practitioners towards the existence of the Pretrial, in which it has been a convention that Pretrial is often associated as the representation of habeas corpus institution. However, habeas corpus, initially interpreted as a restriction on the non-arbitrary authority while executing forcible attempts, is reduced as an administrative inspection of forcible attempts. At the same time, the weaknesses of Law Enforcers as human beings who are independent to interpret subjectively, and are realized in the form of legal action, lose its essence.

\section{Conclusion}

Based on the above descriptions, everyone who is drawn into the criminal justice process is like an object. As a result, in the process of inspection, the method of drawing a conclusion by the Criminal Justice System component starts off an understanding that authority in interpretive cognitive activity is a one-sided authority. The trap (gowerfen-sein) of Law Enforcement Apparatus in the traditional reasoning pattern based on the Continental European legal tradition has omitted a fact that the suspect/defendant is a whole person and not a minor premise to conclude.

On the normative juridical side, there is a distinction between the philosophical foundation that contains the Consideration Considering the CPC. The reasoning pattern to interpret CPC is not based on the philosophical foundation. This is caused by the attempt to maintain the grand narrative, i.e., partiality to the principle of the inquisitoir, although it appears in the form of the accusatoir. Thus, the only solution to this problem is to restore the function of the consideration as a philosophical foundation by examining dialectically towards the CPC. 


\section{References}

1. W.D. Putro, Kritik Terhadap Paradigma Positivisme Hukum, (Yogyakarta, Genta Publishing, 2011).

2. J. Asshiddiqie, Konstitusi dan Konstitusionalisme Indonesia, (Jakarta: Konstitusi Press, 2010).

3. N.Ms. Bakry, Pancasila. Yuridis Kenegaraan, (Yoyakarta: Liberty, 2001).

4. D. Darmodiharjo dan Shidarta, Pokok-Pokok Filsafat Hukum. Apa dan Bagaimana Filsafat Hukum Indonesia, (Jakarta: Gramedia Pustaka Utama, 2002).

5. Notonagoro, Pancasila Ilmiah Populer, (Jakarta: CV. Pantjuran Tudjuh, 1971).

6. N.Ms. Bakry, Orientasi Filsafat Pancasila, (Yogyakarta: Liberty, 1994).

7. Sunoto, Mengenal Filsafat Pancasila. Pendekatan melalui Metafisika, Logika dan Etika, (Yogyakarta: Hanindita Graha Widya, 1995).

8. D. Darmodiharjo dan Shidarta, Pokok-Pokok Filsafat Hukum, (2002).

9. B.A. Sidharta, Refleksi Tentang Struktur Ilmu Hukum. Sebuah Penelitian Tentang Fundasi Kefilsafatan dan Sifat Keilmuan Ilmu Hukum Sebagai Landasan Pengembangan Ilmu Hukum Nasional Indonesia, (Bandung: Mandar Maju, 2009).

10. A.S. Kartohadiprodjo, et.al, Prof Mr. Soedirman Kartodiprodjo tentang Pancasila Sebagai Pandangan Hidup Bangsa Indonesia, (unpublished), (Bandung/Jakarta: tanpa penerbit, 2009).

11. E.W. Suteki dan A. Marwan, Refleksi dan Rekonstruksi Ilmu Hukum Indonesia, (Yogyakarta: Thafa Media, 2012).

12. O. Rosadi, Hukum Kodrat, JDH, 10, 3, (2010).

13. A. Aarnio, A Hermeneutic Approach in Legal Theory. Philosophical Perspective in Jurisprudence, (Helsinki: 1983).

14. K.E. Sapardjaja, Ajaran Sifat Melawan Hukum Materiel Dalam Hukum Pidana Indonesia, (Bandung: Alumni, 2002).

15. K.E. Sapardjaja, [14] 